\title{
Utilization of Zakat Funds on The Welfare Dimensions of The Poor In Aceh Besar (Baitul Mal Mustahiq Case Study)
}

\author{
Ulya Utari, Nurma Sari*, Amri \\ Fakultas Ekonomi dan Bisnis Universitas Syiah Kuala, Aceh \\ *Corresponding author e-mail: nurmasari@unsyiah.ac.id
}

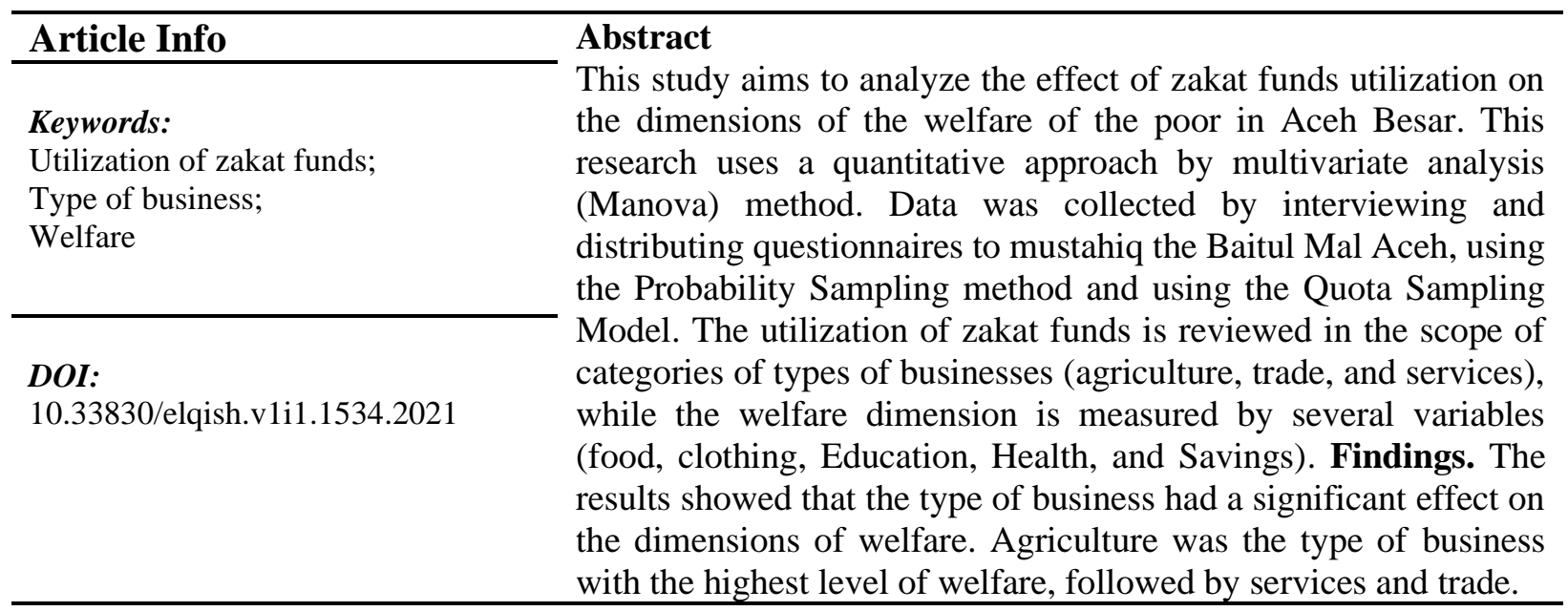

\section{Introduction}

Economic issues bring negative impacts on society, such as unemployment, social inequality, and poverty. According to (BPS, 2019), the number of poor people in Indonesia in September 2018 is approximately 25.67 billion, nearly 831.50 billion people. In Aceh, in 2019, the number of poor people is around 831.50 billion, while in Aceh Besar is 58.90 billion people, with the percentage of poor is $13.92 \%$. (BPS Aceh Besar, 2019).

In 2018, Baitul Mal successfully collected zakat funds amounted to Rp54.014 Million. This amount is higher than the previous year, which is about Rp52.159. Furthermore, it is increased by $3.56 \%$. However, the fund collected is still not able to reduce the number of poverty in Aceh. Thus, Baitul Mal has optimized funds properly by holding economic utilization programs, for instance, providing business capital to underprivileged class citizens.

Research by Khaliq (2012) focused on ZIS Fund Utilization model to empower the economics of poor people. This program is applied to improve micro-business capital. Furthermore, the process is done by several stages based on laws (Undang-Undang). The result shows that this model can increase the economic activity of Mustahiq.

Kasdi (2016) declares that there are three ways of ZISWAF management, managed by BMT Demak. Those ways are one-way management, feedback management, and pilot project management. In addition, the management model of ZISWAF managed by BMT are: social empowerments, which distribute funds to poor people, develop human resources and apply economic empowerment model through Mudharabah Muqayyadah, Wadiah Muqayyadah, and loan without profit sharing.

Many researchers have researched Zakat. One of them is Tanjung, who did research in 2019 and stated that ZIS empowerment has successfully influenced the growth of the micro business of Mustahiq, but it has not reached the prosperous level yet. In their research, Herman and Waluya (2019) analyzed the empowerment funds of ZIS that Koperasi Syariah Benteng Mikro Indonesia manages through housing grants. The results are beneficial for poor inhabitants who have homes to live in but are not suitable. It is proven that one of the factors that lead to poverty is the house 
price. Nurlinda and Nuhirysan (2019) and Wicaksono (2018) examined the effects of ZIS on the welfare of citizens. The LAZISWA organization improves Cirebon people's welfare through economic empowerment programs, social, education, and health have changed the status from Mustahiq to Muzakki (Rani et al., 2020).

Several empowerment models of ZISWAF have been researches. However, only a few articles focused on the effects of the use of Zakat funds from a business levels perspective, which can then relate to the welfare of the business. Moreover, the research about what sorts of business can contribute to those types of people is still limited. This research can reference Baitul Mal to lead business people to choose what businesses are the best fit to decrease the poverty in Aceh. Thus, the model chosen in this research is MANOVA because the researcher assumes that this model is the best to find out the contribution of business models to welfare.

Studying the effect of utilization of Zakat funds is interesting to examine to gain the economic utilization or understanding the business capital. Simultaneously, the funds will be allocated on a smaller scale to various businesses run by Mustahiq. For example, selling fish, stall and making cakes, and traditional Acehnese cakes. Those all sorts of enterprises are considered as "commerce." In addition, Palawija farming businesses, such as celery, candlenut, clove, and other spice farmers, are categorized into "Agriculture" businesses. Moreover, businesses involving sewing, laundry services, barbershops, and bicycle/motorcycle repair shops are categorized into "Services" business types. All types of businesses are chosen by the community/Mustahiq and are carried out to achieve the dimensions of welfare, clothing, food, education, health, and savings for the Mustahiq.

Utilization means exploitation to bring results and benefits as well as forms of exploitation (force) so that they can carry out their duties properly (KKBI). Meanwhile, in another opinion, Fuad. $\mathrm{N}$ defines utilization as an effort to produce and provide benefits. From the meaning above, it can be concluded that utilization is an effort to obtain more and better results or benefits by utilizing all available resources and potentials available. The utilization of zakat funds is divided into several categories. Firstly, consumptive utilization to meet the needs of the eight asnaf groups who are entitled to receive Zakat as stated in the Qur'an. Second, productive utilization is used to run productive businesses to improve people's welfare (Aibak, 2016). Zakat is one of the pillars of Islam, which is socio-economic compared to the other five pillars of Islam. With the pledge of monotheism (shahada), doing prayers, fasting in the obligatory month (Ramadan), doing Hajj for those who are able and participating in paying Zakat, then a person can be considered to be validly entered into the ranks of Muslims and recognized as Islam (Sari, 2017).

Based on observations from time to time, the concept of Zakat does not experience significant changes because the concept of fiqh zakat states that the zakat system is intended to bring Muslim surplus with Muslim deficit parties. The difference is only in the operational problems of collecting and empowering zakat funds (Saripudin, 2016). Therefore, in utilizing and also managing zakat funds as efficiently and effectively as possible, the wisdom of the government or zakat managers is needed. Sari (2017) states that the provision of zakat funds to mustahiq should fulfill consumption needs and can be given in other forms that can be used productively. That is, they can be managed further so that they can benefit continuously and reduce poverty levels.

Nurwati (2008) stated that poverty is a multidimensional problem, meaning that a person's movement is limited due to inability to access, especially economically. (Yulianto Kadji, 2004) Kotze (2004:6) says that the poor are motivated to be relatively better off to reach and get resources through existing opportunities. According to (Itang, 2017) the factors that cause poverty are as follows; low education, laziness to work, geographical location and limited natural resources, and limited employment opportunities. The causes of poverty can be mentioned as unemployment, 
crime, dropouts, and damaged future generations. Suharto (2009) explained that poverty indicators are included legal instruments and service standards that promote the lives of the poor, namely; Type 1: Living status of the poor, Type 2: Family and household environment, Type 3: Surrounding neighborhood, Type 4: Access to essential services, Type 5: Pro-poor allocation of public resources.

Poverty is a problem that hinders the economic welfare of the community. According to the Indonesian dictionary, the word prosperous means safe, secure, prosperous, peace. Prastyaningrum (2009), in his research, mentions three determinants of community welfare, namely Economy, Social Status, and Family. According to Maulana (2008), several indicators can be used to measure the level of welfare of people with the status of Mustahiq, including; the fulfillment of food, clothing, education, health, and having savings.

\section{Research Method}

The type of research used in this research is quantitative research with the MANOVA (Multivariate Analysis of Variance) approach. MANOVA is used to calculate the significance test of the average difference simultaneously between groups for two or more dependent variables (Sutrisno \& Wulandari, 2018).

This experiment uses the $3 \times 4$ factorial 3x4 Multivariate Analysis of Variance (MANOVA) design below:

Table 1. MANOVA Matrix Design

\begin{tabular}{c|c|c|c|c|c|c|c|c|c|c|c}
\hline \multicolumn{10}{c}{ A } & \multicolumn{5}{c}{ A2 } & \multicolumn{4}{|c}{ A3 } \\
\hline Y1 & Y2 & Y3 & Y4 & Y1 & Y2 & Y3 & Y4 & Y1 & Y2 & Y3 & Y4 \\
\hline Y1A1 & Y2A1 & Y3A1 & Y4A1 & Y1A2 & Y2A2 & Y3A2 & Y4A2 & Y1A3 & Y2A3 & Y3A3 & Y4A3 \\
\hline
\end{tabular}

A : Type of Business

A1 : Trade

A2 : Agriculture

A3 : Service

Y1 : Food and Clothing Welfare

Y2 : Educational Welfare

Y3 : Health Welfare

Y4 : Savings Welfare

Y1A1 : Food and Clothing Welfare in Trading Business Type.

Y2A1 : Educational Welfare in Trading Business Types.

Y3A1 : Health Welfare in Trading Business Type.

Y4A1 : Savings Welfare in Trading Business Type.

Y1A2 : Food and Clothing Welfare in Agricultural Business Types.

Y2A2 : Educational Welfare in Agricultural Business Types.

Y3A2: Health Welfare in Agricultural Business Types.

Y4A2 : Savings Welfare in Agricultural Business Types.

Y1A3 : Food and Clothing Welfare in Service Business Type.

Y2A3 : Educational Welfare in Service Business Types.

Y3A3 : Health Welfare in Service Business Type.

Y4A3 : Savings Welfare in Service Business Types. 
The population in this study is all productive zakat recipients from baitul mal amounted to 345 mustahiq. Based on the Quota Sampling technique, there are 90 samples from 345 populations, which then the sample is set with 30 respondents from trading business types, 30 respondents from agricultural business types, and 30 respondents from service businesses. The independent variable (A) is the utilization of Baitul Mal zakat funds in the type of business (A). While the dependent variable (Y) is the dimension of community welfare in Aceh Besar, which consists of several dependent variables; food and clothing (Y1), education (Y2), health (Y3), savings (Y4). The steps used in data analysis are normality tests, which are homogeneity, homogeneity of the covariance variance matrix, and hypothesis testing.

The MANOVA (Multivariate Analysis of Variance) Hypothesis Test uses statistical test techniques to see the relationship between several independent variables (free/treatment) and two or more dependent (bound) variables simultaneously (Setiawan, 2018). In MANOVA, several test statistics can be used to make decisions, namely:

a. Pillai's Trace is a statistical test that is very appropriate to use when the assumption of homogeneity of the variance-covariance matrix is inadequate, the sample sizes are small, and test results contradict one another. The higher the Pillai's Trace statistical value, the greater the influence on the model. Pillai's Trace test statistics are formulated as:

$$
\begin{gathered}
P=\sum_{i=1}^{p}\left(\frac{\lambda_{i}}{1+\lambda_{i}}\right)=\operatorname{tr} \lambda_{i}\left(1+\lambda_{i}\right)^{-1}=\operatorname{tr} \frac{|B|}{|B+W|}(3-1) \\
\lambda_{1}, \lambda_{2}, \ldots, \lambda \text { are characteristic roots of }(\mathrm{W})^{-1}(\mathrm{~B}) \\
(\mathrm{W})=\text { matriks varians-kovarians error on MANOVA } \\
(\mathrm{B})=\text { treatment matriks varians-kovarians on MANOVA }
\end{gathered}
$$

b. Wilk's Lambda is a test statistic used when more than two groups of independent variables are found and the assumption that the variance-covariance matrix homogeneity test has been adequate. The lower Wilk's Lambda statistical value, the greater the influence on the model. Wilk's Lambda values range from 0-1. Wilk's Lambda test statistic is formulated as:

$$
U=\prod_{i=1}^{p}\left(1+\lambda_{i}\right)^{-1}=\frac{|W|}{|B+W|}(3-2)
$$

c. Hotelling's Trace is a test statistic used when there are only two groups of independent variables. The higher the statistical value of Hotelling's Trace, the greater the influence on the model. Hotelling's Trace Value > Pillai's Trace. Hotelling's test statistics are formulated as:

$$
T=\sum_{i=1}^{p} \lambda_{i}=\operatorname{tr} \lambda_{i}=\operatorname{tr}(W)^{-1}(B)(3-3)
$$

d. Roy's Largest Root is a test statistic used with the assumption that the variance-covariance homogeneity test is adequate. The higher the Roy's Largest Root statistic, the greater the influence on the model. Value Roy's Largest Root > Hotelling's Trace > Pillai's Trace. In terms of violating the assumption of multivariate normality, this statistic is less robust than the other test statistics. Roy's Largest Root test statistic is formulated as:

$$
\begin{aligned}
\mathrm{R} & =\lambda_{\text {maks }}=\text { maks }\left(\lambda_{1}, \lambda_{2}, \ldots, \lambda_{\mathrm{p}}\right)(3-4) \\
& =\text { max characteristics on }(\mathrm{W})^{-1}(\mathrm{~B})
\end{aligned}
$$


After the test is carried out and the results are significant, if there are differences between groups (treatments), further tests must be carried out to see in forming a difference between groups which variable has the most influence. This test needs to be done to see which variables have a significant effect on differences between groups because not all variables are the same.

Afterward, a follow-up test was conducted to determine the differences between each individual in the group based on the variables that make up the differences between groups. This procedure is called the Post Hoc test. The calculation process is carried out using a data processing program by IBM SPSS Statistics ver.25 with several general Post Hoc procedures such as; Tukey's method (HSD), Scheffe's method, Fisher's method (LSD), Duncan's test, and Newman's test (Setiawan, 2018).

\section{Results and Discussions}

The characteristics of the respondents in this study consisted of 90 people who are the recipients of the productive zakat fund utilization program in Aceh Besar district, as follows:

Table 2. Respondent Characteristics

\begin{tabular}{lll}
\hline Characteristics & $\mathbf{N}$ & Percentage (\%) \\
\hline Gender & 25 & 25,02 \\
Man & 65 & 64,98 \\
Female & & \\
\hline Occupation & 30 & 33,3 \\
Farmer & 27 & 30 \\
Micro Business/ Trade & 2 & 2,2 \\
Civil Servant & 31 & 34,5 \\
Service Provider & & \\
\hline Income & 15 & 16,7 \\
$<500.000$ & 27 & 30 \\
$500.000-1.000 .000$ & 34 & 37,8 \\
$1.000 .000-2.000 .000$ & 14 & 15,5 \\
$2.000 .000-3.000 .000$ & $\mathbf{9 0}$ & $\mathbf{1 0 0 , 0}$ \\
\hline Aggregate & & \\
\hline
\end{tabular}

Source : primary data

Based on table 2, it can be seen from 90 respondents dominated mainly by women as many as 64 people (64.98 percent), the remaining 25 men (25.02 percent). Therefore, it can be concluded that the recipients of productive zakat from Baitul Mal are dominated by female mustahiq. Based on the occupation, 31 people (34.5\%) worked as traders/micro-businesses, 30 people $(33.3 \%)$ as the next farmer, and there were 27 people (30\%) as service providers. On the other hand, two people worked as civil servants $(2,2 \%)$. Civil servants in this study are determined only by civil servants from class I. This indicates that the respondents in this study are dominated by Mustahiq, who work in micro-enterprises/traders.

On the other hand, income characteristics show that the estimated monthly income consists of mustahiq with an income of less than Rp. 500,000 with 15 people or (16.7\%). The income level of Rp. 500,000 to Rp. 1,000,000 is a total of 27 people (30\%). On the other hand, income from IDR $1,000,000$ to IDR $2,000,000$ is a total of 34 people $(37.8 \%)$. Furthermore, those who earn between Rp. 2,000,000 to Rp. 3,000,000 are 14 people or (15.5\%). Thus, it can be concluded that 
the recipients of productive zakat utilization are Musahik who have an average income of IDR $1,000,000$ to IDR $2,000,000$ or as much as $(37.8 \%)$.

Table 3. Statistics Description

\begin{tabular}{lllll}
\hline & Empowerment Model & Mean & Std. Deviation & $\mathrm{N}$ \\
\hline Clothing food & Trading & 78.3667 & 6.37064 & 30 \\
& Agriculture & 85.2667 & 4.74838 & 30 \\
& Service & 81.2000 & 7.09249 & 30 \\
& Total & 81.6111 & 6.71355 & 90 \\
\hline Education & Trading & 75.0000 & 6.09692 & 30 \\
& Agriculture & 81.2333 & 5.97514 & 30 \\
& Service & 79.0000 & 8.44046 & 30 \\
& Total & 78.4111 & 7.32687 & 90 \\
\hline Health & Trading & 77.0667 & 7.35285 & 30 \\
& Agriculture & 82.7667 & 5.98667 & 30 \\
& Service & 80.1667 & 7.89624 & 30 \\
& Total & 80.0000 & 7.42301 & 90 \\
\hline Savings & Trading & 76.2000 & 6.17224 & 30 \\
& Agriculture & 82.1000 & 4.57391 & 30 \\
& Service & 79.0333 & 7.62249 & 30 \\
& Total & 79.1111 & 6.63570 & 90 \\
\hline
\end{tabular}

The results of the descriptive statistical analysis test in table 3 show that the average value on the variables of clothing, food, education, health, and savings is good, that is seen from the comparison of the average value more than the standard deviation (mean Std. Deviation). The results of the normality prerequisite test are carried out using the Kolmogorov-Smirnov test with a significance level of 0.05 . The summary of the results of the normality test is presented in the following table:

Table 4. Normality Test Results

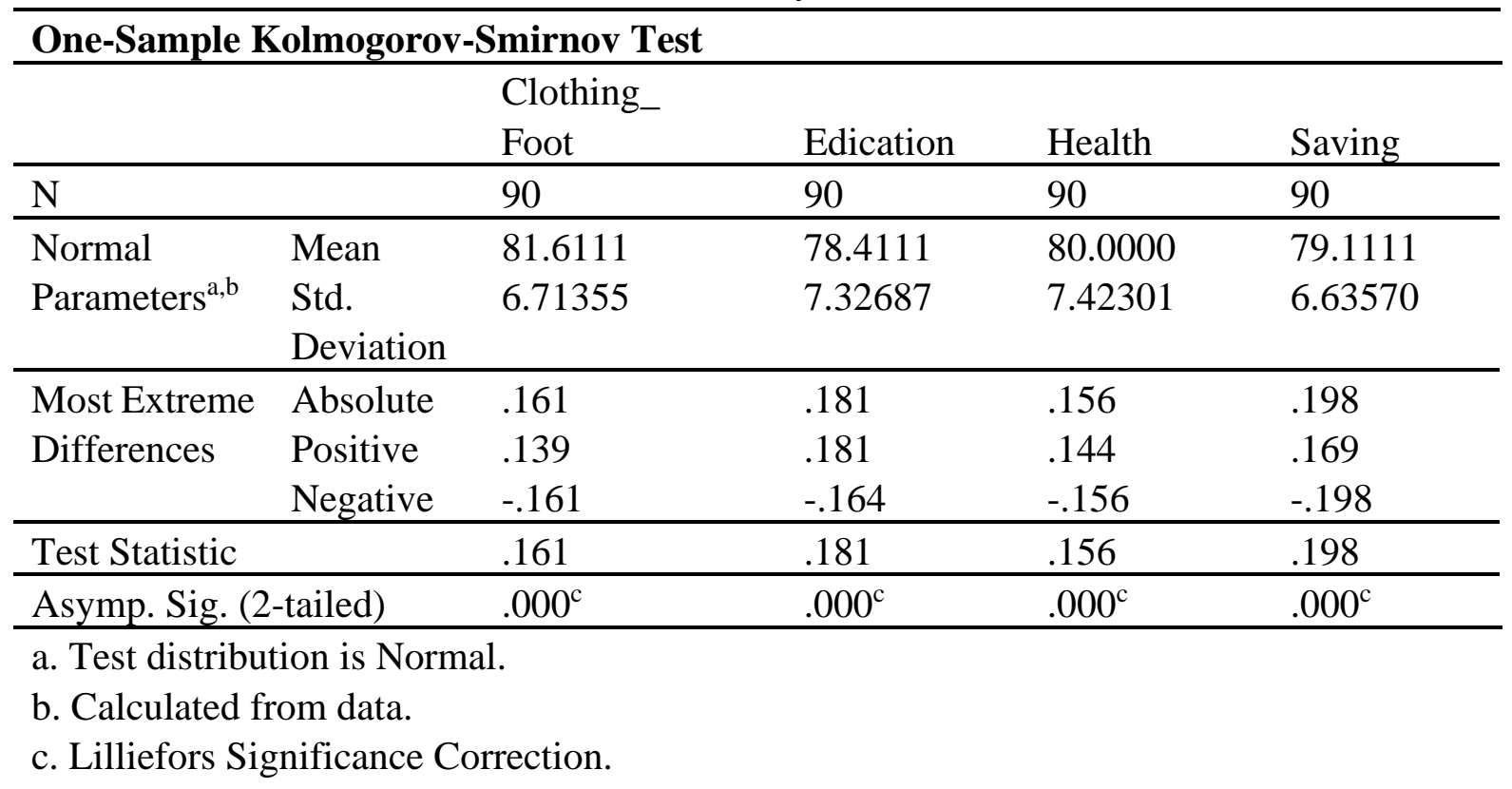


The results in table 4 show that all groups of normality data tested with the KolmogorovSmirnov test yielded sig. $<0.05$. Therefore, it can be concluded that all data groups in this study are not normally distributed, but the normality test for the Manova test is seen from the results of Box's M test. The homogeneity of variance test used Levene's test on SPSS. The results of which can be seen in Fig. following table:

Table 5. Homogeneity Varian test

\begin{tabular}{|c|c|c|c|c|c|}
\hline \multicolumn{6}{|c|}{ Levene's Test of Equality of Error Variances $^{a}$} \\
\hline & & $\begin{array}{l}\text { Levene } \\
\text { Statistic }\end{array}$ & df1 & df2 & Sig. \\
\hline \multirow[t]{4}{*}{ Clothing Food } & Based on Mean & 2.362 & 2 & 87 & .100 \\
\hline & Based on Median & 1.333 & 2 & 87 & .269 \\
\hline & $\begin{array}{l}\text { Based on Median and with } \\
\text { adjusted df }\end{array}$ & 1.333 & 2 & 75.744 & .270 \\
\hline & Based on trimmed mean & 2.347 & 2 & 87 & .102 \\
\hline \multirow[t]{4}{*}{ Edication } & Based on Mean & 2.698 & 2 & 87 & .073 \\
\hline & Based on Median & 2.817 & 2 & 87 & .065 \\
\hline & $\begin{array}{l}\text { Based on Median and with } \\
\text { adjusted df }\end{array}$ & 2.817 & 2 & 79.811 & .066 \\
\hline & Based on trimmed mean & 2.689 & 2 & 87 & .074 \\
\hline \multirow[t]{4}{*}{ Health } & Based on Mean & 1.339 & 2 & 87 & .267 \\
\hline & Based on Median & 1.413 & 2 & 87 & .249 \\
\hline & $\begin{array}{l}\text { Based on Median and with } \\
\text { adjusted df }\end{array}$ & 1.413 & 2 & 86.479 & .249 \\
\hline & Based on trimmed mean & 1.279 & 2 & 87 & .283 \\
\hline \multirow[t]{4}{*}{ Saving } & Based on Mean & 2.665 & 2 & 87 & .075 \\
\hline & Based on Median & 2.009 & 2 & 87 & .140 \\
\hline & $\begin{array}{l}\text { Based on Median and with } \\
\text { adjusted df }\end{array}$ & 2.009 & 2 & 79.606 & .141 \\
\hline & Based on trimmed mean & 2.782 & 2 & 87 & .067 \\
\hline
\end{tabular}

Tests the null hypothesis that the error variance of the dependent variable is equal across groups.

a. Design: Intercept + Jenis_Usaha

Table 5 shows the results of the homogeneity test of 4 groups of business types on food and clothing welfare obtained a value of $\operatorname{sig}=0.100$ which means the value of sig. $>0.05$. It can be concluded that the variance of food and clothing welfare between groups of trading, agricultural, and service business types is homogeneous. The results of the homogeneity test of 4 groups of business types on education obtained a value of sig $=0.073$ which means the value of sig. $>0,05$. It can be concluded that the variance education welfare between groups of trading, agricultural, and service business types is homogeneous. The results of the homogeneity test of 4 groups of business types on health obtained a value of sig $=0.267$ which means the value of sig. $>0,05$. It can be concluded that the variance health welfare between groups of trading, agricultural, and service business types is homogeneous. The results of the homogeneity test of 4 groups of business types on savings obtained a value of $\operatorname{sig}=0.075$ which means the value of sig. $>0,05$. It can be concluded that the variance savings welfare between groups of trading, agricultural, and service business types is homogeneous. 
Furthermore, to find out whether the variable X (Empowerment of Zakat Funds) affects the YI variable (food clothing), Y2 variable (education), Y3 variable (health), and Y4 variable (investment), we test the homogeneity of the variance - covariant matrix using Box's test of equality of covariate matrices. The test results can be seen in the following table:

Table 6. Box's Test of Equality of Covariance Matrices ${ }^{a}$

\begin{tabular}{ll}
\hline Box's Test of Equality of Covariance Matrices \\
\end{tabular}

Tests the null hypothesis that the observed covariance matrices of the dependent variables are equal across groups.

a. Design: Intercept + Jenis_Usaha

Value Box's $\mathrm{M}=25.971$ while the value in sig 0,232 according to the existing criteria if the value of sig $>0,05$ then $\mathrm{H} 0$ is accepted, so it can be concluded that covariance matrix $\mathrm{Y}$ variable (Clothing food, education, health, saving) with covariance matrix X variable (Utilization of zakat funds) is homogeneous. Based on the data from a normally distributed population, the variance in each group is homogeneous. The variance-covariance matrix between groups of business types is homogeneous, the assumption of the prerequisite test results in the MANOVA analysis test has been fulfilled. By using IBM SPSS Statistic Ver.25, hypothesis testing is done by using MANOVA (Multivariate of Variance) analysis technique. Below, the results of hypothesis testing are described in the table:

Table 7. Multivariate Test

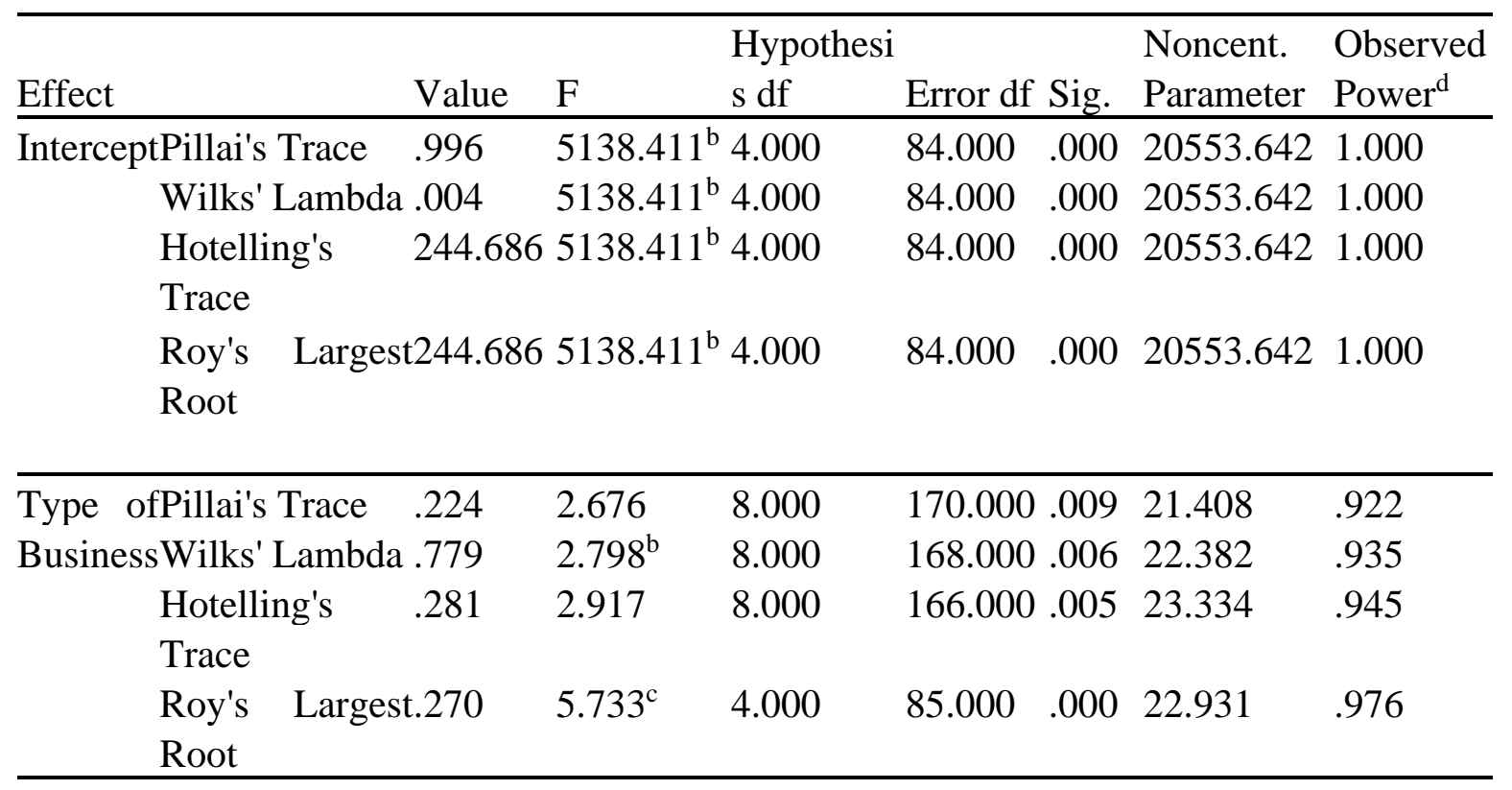
a. Design: Intercept + Jenis_Usaha
b. Exact statistic
c. The statistic is an upper bound on $\mathrm{F}$ that yields a lower bound on the significance level.
d. Computed using alpha $=.05$ 
The results in table 7 show the comparison of the average dimensions of welfare with the type of business. There are four statistical tests: Pillai's Trace, Wilk's Lambda, Hotelling' Trace, and Roy's Largers Root. These four tests are based on the eigenvalues where the formula for each statistical test. Hotelling's Trace value shows a positive value, which is 244,686 . Hotelling's Trace value is more significant than Pillai's Trace value. The Hotelling's Trace value shows a significant influence on the type of business, but in some cases, if the eigen value is small, the Hotelling's Trace and Pillai's Trace values will be close together. This shows an indication that there is no significant effect on the type of business.

The value of Roy's Largest Root is positive, which is about 244,686. The value of Roy's Largest Root is always less than or equal to the value of Hotelling's Trace. This value indicates a significant influence on the type of business taken. In the line of business type, the significance figures were tested using Pillai's Trace, Wilk's Lambda, Hotelling's Trace, and Roy's Largest Root procedures. The first four procedures show a significant number below 0.05 (i.e., 0.009; 0.006; 0.005 and 0.000 ), then $\mathrm{H} 0$ is rejected, so it can be concluded that there is a significant effect of type of business on the dimensions of welfare, clothing, food, education, health, and saving. Between-Subjects Effect Test describes the univariate model testing as shown in the table below:

Table 8. Test Of Between-Subjects Effect

\begin{tabular}{|c|c|c|c|c|c|c|c|c|}
\hline Source & $\begin{array}{l}\text { Dependent } \\
\text { Variable }\end{array}$ & $\begin{array}{l}\text { Type III Sun } \\
\text { of Squares }\end{array}$ & $\mathrm{df}$ & Mean Square & $\mathrm{F}$ & Sig. & $\begin{array}{l}\text { Noncent. } \\
\text { Parameter }\end{array}$ & $\begin{array}{l}\text { Observed } \\
\text { Power }^{\mathrm{e}}\end{array}$ \\
\hline Corrected & Clothing food & $721.756^{\mathrm{a}}$ & 2 & 360.878 & 9.544 & .000 & 19.088 & .977 \\
\hline \multirow[t]{3}{*}{ Model } & Education & $598.422^{\mathrm{b}}$ & 2 & 299.211 & 6.229 & .003 & 12.457 & .884 \\
\hline & Health & $488.600^{c}$ & 2 & 244.300 & 4.814 & .010 & 9.627 & .785 \\
\hline & Saving & $522.422^{\mathrm{d}}$ & 2 & 261.211 & 6.691 & .002 & 13.382 & .906 \\
\hline \multirow[t]{4}{*}{ Intercept } & Clothing food & 599433.611 & 1 & 599433.611 & 15853.051 & .000 & 15853.051 & 1.000 \\
\hline & Education & 553347.211 & 1 & 553347.211 & 11518.781 & .000 & 11518.781 & 1.000 \\
\hline & Health & 576000.000 & 1 & 576000.000 & 11349.368 & .000 & 11349.368 & 1.000 \\
\hline & Saving & 563271.111 & 1 & 563271.111 & 14428.108 & .000 & 14428.108 & 1.000 \\
\hline Type & ofClothing food & 721.756 & 2 & 360.878 & 9.544 & .000 & 19.088 & .977 \\
\hline \multirow[t]{3}{*}{ Business } & Education & 598.422 & 2 & 299.211 & 6.229 & .003 & 12.457 & .884 \\
\hline & Health & 488.600 & 2 & 244.300 & 4.814 & .010 & 9.627 & .785 \\
\hline & Saving & 522.422 & 2 & 261.211 & 6.691 & .002 & 13.382 & .906 \\
\hline \multirow[t]{4}{*}{ Error } & Clothing food & 3289.633 & 87 & 37.812 & & & & \\
\hline & Education & 4179.367 & 87 & 48.039 & & & & \\
\hline & Health & 4415.400 & 87 & 50.752 & & & & \\
\hline & Saving & 3396.467 & 87 & 39.040 & & & & \\
\hline \multirow[t]{4}{*}{ Total } & Clothing food & 603445.000 & 90 & & & & & \\
\hline & Education & 558125.000 & 90 & & & & & \\
\hline & Health & 580904.000 & 90 & & & & & \\
\hline & Saving & 567190.000 & 90 & & & & & \\
\hline Corrected & Clothing food & 4011.389 & 89 & & & & & \\
\hline \multirow[t]{3}{*}{ Total } & Education & 4777.789 & 89 & & & & & \\
\hline & Health & 4904.000 & 89 & & & & & \\
\hline & Saving & 3918.889 & 89 & & & & & \\
\hline
\end{tabular}

a. R Squared $=.180$ (Adjusted R Squared $=.161$ ) 
b. R Squared $=.125$ (Adjusted R Squared $=.105$ )

c. $\mathrm{R}$ Squared $=.100$ (Adjusted R Squared $=.079)$

d. $\mathrm{R}$ Squared $=.133$ (Adjusted R Squared $=.113$ )

e. Computed using alpha $=.05$

Based on the table above, it can be seen that the value of sig. for the results of the food and clothing welfare test of $0.00<0.05$, which concluded that $\mathrm{H}_{0}$ is rejected. It can be concluded that there is a significant influence between the types of business on food and clothing welfare. Table 8 also describes the value of sig. the results of the education welfare test are 0.003 , the health welfare test is 0.010 , and the savings welfare test is 0.002 which are all $<0.005$, which then concluded $\mathrm{H}_{0}$ is rejected. It is concluded that there is also a significant effect between the type of business on the welfare of education, health, and savings. Multiple comparison testing aims to select the independent variable that has the most influence on the dependent variable. In this test, we will see which type of business has the greatest influence on various dimensions of welfare as described in the following table:

Table 9. Multiple Comparison Test

\begin{tabular}{|c|c|c|c|c|c|c|c|}
\hline \multicolumn{8}{|l|}{ Bonferroni } \\
\hline \multirow{2}{*}{$\begin{array}{l}\text { Dependent } \\
\text { Variable }\end{array}$} & \multirow{2}{*}{$\begin{array}{l}\text { (I) } \\
\text { Empowerment } \\
\text { model }\end{array}$} & \multirow{2}{*}{$\begin{array}{l}(\mathrm{J}) \\
\text { Empowerment } \\
\text { model }\end{array}$} & \multirow{2}{*}{$\begin{array}{l}\text { Mean } \\
\text { Difference } \\
(\mathrm{I}-\mathrm{J})\end{array}$} & \multirow{2}{*}{\multicolumn{2}{|c|}{ Std. Error Sig. }} & $\begin{array}{l}95 \% \\
\text { Interval } \\
\end{array}$ & Confidence \\
\hline & & & & & & $\begin{array}{l}\text { Lower } \\
\text { Bound }\end{array}$ & $\begin{array}{l}\text { Upper } \\
\text { Bound }\end{array}$ \\
\hline \multirow{2}{*}{\multicolumn{2}{|c|}{ Clothing foodTrading }} & Agriculture & $-6.9000^{*}$ & 1.58770 & .000 & -10.7758 & -3.0242 \\
\hline & & Service & -2.8333 & 1.58770 & .233 & -6.7091 & 1.0425 \\
\hline & \multirow[t]{2}{*}{ Agriculture } & Trading & $6.9000^{*}$ & 1.58770 & .000 & 3.0242 & 10.7758 \\
\hline & & Service & $4.0667^{*}$ & 1.58770 & .036 & .1909 & 7.9425 \\
\hline & \multirow[t]{2}{*}{ Service } & Trading & 2.8333 & 1.58770 & .233 & -1.0425 & 6.7091 \\
\hline & & Agriculture & $-4.0667^{*}$ & 1.58770 & .036 & -7.9425 & -.1909 \\
\hline \multirow[t]{6}{*}{ Education } & \multirow[t]{2}{*}{ Trading } & Agriculture & $-6.2333^{*}$ & 1.78958 & .002 & -10.6020 & -1.8647 \\
\hline & & Service & -4.0000 & 1.78958 & .084 & -8.3686 & .3686 \\
\hline & \multirow[t]{2}{*}{ Agriculture } & Trading & $6.2333^{*}$ & 1.78958 & .002 & 1.8647 & 10.6020 \\
\hline & & Service & 2.2333 & 1.78958 & .646 & -2.1353 & 6.6020 \\
\hline & \multirow[t]{2}{*}{ Service } & Trading & 4.0000 & 1.78958 & .084 & -.3686 & 8.3686 \\
\hline & & Agriculture & -2.2333 & 1.78958 & .646 & -6.6020 & 2.1353 \\
\hline \multirow[t]{6}{*}{ Health } & \multirow[t]{2}{*}{ Trading } & Agriculture & $-5.7000^{*}$ & 1.83942 & .008 & -10.1903 & -1.2097 \\
\hline & & Service & -3.1000 & 1.83942 & .287 & -7.5903 & 1.3903 \\
\hline & \multirow[t]{2}{*}{ Agriculture } & Trading & $5.7000^{*}$ & 1.83942 & .008 & 1.2097 & 10.1903 \\
\hline & & Service & 2.6000 & 1.83942 & .483 & -1.8903 & 7.0903 \\
\hline & \multirow[t]{2}{*}{ Service } & Trading & 3.1000 & 1.83942 & .287 & -1.3903 & 7.5903 \\
\hline & & Agriculture & -2.6000 & 1.83942 & .483 & -7.0903 & 1.8903 \\
\hline \multirow[t]{6}{*}{$\overline{\text { Saving }}$} & \multirow[t]{2}{*}{ Trading } & Agriculture & $-5.9000^{*}$ & 1.61328 & .001 & -9.8382 & -1.9618 \\
\hline & & Service & -2.8333 & 1.61328 & .248 & -6.7716 & 1.1049 \\
\hline & \multirow[t]{2}{*}{ Agriculture } & Trading & $5.9000^{*}$ & 1.61328 & .001 & 1.9618 & 9.8382 \\
\hline & & Service & 3.0667 & 1.61328 & .182 & -.8716 & 7.0049 \\
\hline & \multirow[t]{2}{*}{ Service } & Trading & 2.8333 & 1.61328 & .248 & -1.1049 & 6.7716 \\
\hline & & Agriculture & -3.0667 & 1.61328 & .182 & -7.0049 & .8716 \\
\hline
\end{tabular}

Based on observed means.

The error term is Mean Square (Error) $=39.040$. 
*. The mean difference is significant at the .05 level.

The results in table Multiple Comparisons shows that:

1)Between agriculture (A2) and trade (A1) has a Mean Difference of 6.9000. This shows that the welfare of food and clothing (Y1) in agriculture (A2) is better than trade (A1)

2)Between agriculture (A2) and service (A3) has a Mean Difference of 4.0667. This shows that the welfare of food and clothing (Y1) in agriculture (A2) is better than service (A3).

3)Between trade (A1) and service (A3) has a Mean Difference of 2.8333. This shows that welfare of food and clothing (Y1) in service (A3) is better than trade (A1).

4)Between agriculture (A2) and trade (A1) has a Mean Difference of 6.2333. This shows that the welfare education (Y2) in agriculture (A2) is better than trade (A1).

5)Between agriculture (A2) and service (A3) has a Mean Difference of 2.2333. This shows that the welfare education (Y2) in agriculture (A2) is better than service (A3).

6)Between trade (A1) and service (A3) has a Mean Difference of 4.0000. This shows that the welfare education (Y2) in service (A3) is better than trade (A1).

7)Between agriculture (A2) and trade (A1) has a Mean Difference of 5.7000. This shows that the welfare health (Y3) in agriculture (A2) is better than trade (A1).

8)Between agriculture (A2) and service (A3) has a Mean Difference of 2.6000. This shows that the welfare health (Y3) in agriculture (A2) is better than service (A3).

9)Between trade (A1) and service (A3) has a Mean Difference of 3.1000. This shows that the welfare health (Y3) in service (A3) is better than trade (A1).

10) Between agriculture (A2) and tade (A1) has a Mean Difference of 5.9000. This shows that the welfare saving (Y4) in agriculture (A2) is better than trade (A1).

11) Between agriculture (A2) and service (A3) has a Mean Difference of 3.0667. This shows that the welfare saving (Y4) pada pertanian (A2) is better than service (A3).

12) Between trade (A1) and service (A3) has a Mean Difference of 2.8333. This shows that the welfare saving (Y4) in service (A3) is better than trade (A1).

This study aims to determine the effect of zakat funds utilization on the dimensions of community welfare. This section will discuss the effect of the efficient use of zakat funds in the form of business capital on the types of trading, agricultural, and service businesses in order to improve welfare from various dimensions such as welfare in food, clothing, education, health, and savings in the community or mustahiq who receive the benefits of productive zakat in Indonesia. Aceh Besar. In this test, the normality test and homogeneity test were carried out. After the two tests are carried out, a hypothesis test will be carried out using a multivariate test or MANOVA using the SPSS 25.0 program.

Based on the data obtained, the results of hypothesis testing, and discussion of research results, it can be concluded that there is a significant effect of the type of business on the welfare of food, clothing, education, health, and community savings/mustahiq in Aceh Besar in a multivariate manner. It is evidenced by the value of Fo starting from $=26,676$ to 5,733 with each sig. $=0.009,0.006,0.005$, and 0.000 which are $<0.05$. For the welfare dimension variable:

1. There is a significant effect of the type of business on the welfare of the community/mustahiq. This is evidenced by the value of $\mathrm{Fo}=9.544$ and sig. $=0.000<0,05$.

2. There is a significant effect of the type of business on the welfare education of the community/mustahiq. This is evidenced by the value of $F_{0}=6.299$ and sig. $=0.003<0,05$.

3. There is a significant effect of the type of business on the welfare health of the community/mustahiq. This is evidenced by the value of $F_{0}=4.814$ and sig. $=0.010<0,05$. 
4. There is a significant effect of the type of business on the welfare saving of the community/mustahiq. This is evidenced by the value of $F_{0}=6.691$ and sig. $=0.002<0,05$. The results of the multiple comparison test can be seen that the type of business that provides better welfare, clothing, food, education, health, and savings is occupied by agriculture, second by services, and third by trade. The results of this study are strengthened by research conducted by (Wicaksono, 2018) where the utilization/empowerment of zakat funds have a significant effect on the consumption, income, and savings of agricultural households. The same results were also found in research (Tanjung, 2019) which states that the empowerment of productive ZIS funds has a significant effect on the growth of mustahiq micro enterprises but has not shown a significant effect on the level of welfare. Likewise, (Nurinda, Zuhirysan, 2019) found that there was a significant effect of the utilization of productive zakat on improving people's welfare, but it needed to be balanced with training for mustahiq.

\section{Conclusions}

The study results stated that the type of trade, agriculture, and service business variables had a significant effect on the welfare of food, clothing, education, health, and savings. This means that any changes in the independent variable, namely the type of business, will affect the welfare of food, clothing, education, health, and savings for the people/mustahiq of Aceh Besar. It can also be concluded that the type of agricultural business is the type of business that contributes the most to the fulfillment of various dimensions of community welfare / mustahiq Aceh Besar, supported by the size of agricultural land in the area, followed by the type of business services and trade.

\section{References}

Adib Abadi. (2006). Problematika Penentuan Sampel Dalam Penelitian Bidang Perumahan Dan Permukiman. DIMENSI (Jurnal Teknik Arsitektur), 34(2), 138-146.

Aibak, K. (2016). Pengelolaan Zakat Di Badan Amil Zakat Nasional Kabupaten Tulungagung Dalam Perspektif Maqashid Al-Syariah. Ahkam: Jurnal Hukum Islam, 4(2), 247-288. https://doi.org/10.21274/ahkam.2016.4.2.247-288

A.Muri Yusuf. (2014). Metode Penelitian. Jakarta: kencana.

Amymie, F. (2017). Optimalisasi Pendistribusian Dan Pendayagunaan Dana Zakat Dalam Pelaksanaan Tujuan Program Pembangunan Berkelanjutan (Sdgs). Anida (Aktualisasi Nuansa Ilmu Dakwah), 17(1), 1-18.

BPS. (2019). Statistik Profil Kemiskinan di Indonesia September 2018. In Berita Resmi Statistik (pp. 1-12).

BPS Aceh Besar. (2018). Aceh Besar Dalam Angka 2018. (S. S. Sosial, S. S. Produksi, S. S. Distribusi, S. N. Wialayah, \& dan D. S. Seksi Integrasi, Pengolahan, Eds.). Aceh besar: BPS Kabupaten Aceh Besar. https://doi.org/1102001.1108.

Fajriawati. (2016). Dampak Perekonomian Terhadap Masyarakat Miskin Di Lingkungan Kampung Nelayan Kecamatan Medan Labuhan. Jurnal Ekonomikawan, 1-13.

Feria, I. (2019). Pengaruh Model Pembelajaran Advance Organizer Terhadap Keterampilan Berpikir Kritis Dan Sikap Ilmiah Peserta Didik Kelas VIII Materi Gerak Benda SMP Negeri 1 Pubian Lampung Tengah (Doctoral Dissertation). (Uin Raden Intan Lampung).

Haryanto, C. A., \& Laila, N. (2015). Dampak Pendayagunaan Infaq Produktif Terhadap Peningkatan Pendapatan Pada Mustahiq YDSF (Yayasan Dana Sosial Al-Falah) di Kediri. 
Jurnal Ekonomi Syariah Teori dan Terapan, 1(10).

Itang. (2017). Faktor Faktor Penyebab Kemiskinan. Tazkiya, 16(01), 1-30.

Kasdi, A. (2016). Filantropi Islam Untuk Pemberdayaan Ekonomi Umat (Model Pemberdayaan ZISWAF di BMT Se-Kabupaten Demak ). Journal Iqtishadia 9(2), 227-245.

Kholiq, A. (2012). Pendayagunaan zakat, infak dan sedekah untuk pemberdayaan ekonomi masyarakat miskin di kota semarang, Jurnal Riptek, 6(I), 1-7.

Maulana, H. (2008). Analisa Distribusi Zakat Dalam Meningkatkan Kesejahteraan Mustahik (Studi Baz Kota Bekasi), 1-84.

Nasution, L. M. (2017). Statistik Deskriptif. Jurnal Hikmah, 14(1), 49-55.

Nurlinda \& Nurhysan, M. ((2019)). Pemanfaatan ZIS Dalam Meningkatkan Kesejahteraan Umat. AL-AMWAL: Jurnal Ekonomi Dan Perbankan Syariah 11 (1) DOI: 10.24235/amwal.v11i1.4227, 59-70.

Nurwati, N. (2008). Kemiskinan: Model Pengukuran, Permasalahan dan Alternatif Kebijakan. Jurnal Kependudukan Padjadjaran, 10(1), 1-11.

Prastyaningrum, W. (2009). Analisis Faktor Yang Mempengaruhi Kesejahteraan Masyarakat Kecamatan Tembarak Kbupaten Temanggung. Jurnal Unnes, 80.

Rani, V. \&. (2020). Pemberdayaan Pengelolaan ZIS Dalam Upaya Meningkatan Kesejahteraan Ekonomi Masyarakat Di LAZISWA Masjid At Taqwa Kota Cirebon. Jurnal Indonesia Sosial Sains 1(1), 1-7.

Sari, N. (2017). Zakat Sebagai Kebijakan Fiskal Pada Masa Kekhalifah Umar Bin Khattab. Jurnal Perspektif Ekonomi Darussalam, 1(2), 172-184. https://doi.org/10.24815/jped.v1i2.6552

Saripudin, U. (2016). Filantropi Islam dan Pemberdayaan Ekonomi. Jurnal Bisnis Dan Manajemen Islam, 4(Desember), 165-185. Retrieved from http://mhakicky.blogspot.com/2012/11/filantropi-Islam.html

Setiawan, T. H. (2018). Efektivitas Media Pembelajaran Terhadap Penalaran Dan Komunikasi Matematika Siswa. Jurnal Saintika Unpam, 1(1), 56-73.

Sodiq, A. (2016). Konsep Kesejahteraan Dalam Islam. Equilibrium, 3(2), 380- 405. https://doi.org/http://dx.doi.org/110.21043/equilibrium.v3i2.1268

Sudarwati, Y., \& Sayekti, N. W. (2011). Konsep Sentralisasi Sistem Pengelolaan Zakat Dalam Pemberdayaan Ekonomi Umat. Jurnal Ekonomi dan Kebijakan Publik, 2(1), 559-584

Sugiharto. (2007). Tingkat Kesejahteraan Masyarakat Nelayan Desa Benua Baru Ilir Berdasarkan Indikator Badan Pusat Statistik. Jurnal Ekonomi dan Perencanaan. 4(2), 32-36.

Suharto, E. (2009). Menengok Kriteria Kemiskinan Di Indonesia: Menimbang Indikator Kemiskinan Berbasis Hak. Jurnal Analsis Sosial. 14(2), 31-39.

Sutrisno, \& Wulandari, D. (2018). Multivariate Analysis of Variance (manova) untuk Memperkaya Hasil Penelitian Pendidikan. Aksioma, 9(1), 37-53.

Waluya, D. H. (2019). Peran Ziswaf Dalam Pemberdayaan Masyarakat Miskin Di Provinsi Banten. AL-INFAQ: Jurnal Ekonomi Islam 10 (1), 1-12.

Yulianto Kadji. (2004). Kemiskinan Dan Konsep Teoritisnya. Revista de Critica Literaria Latinoamericana, 59(1), 23-51. 